\title{
DR-1658
}

\section{Effect of Osmo Dehydration on Quality Attributes of Bilimbi (Averroha bilimbi) Fruits}

\author{
G.S. Aparna, P.R. Geetha Lekshmi, C. Mini
}

10.18805/ajdfr.DR-1658

\begin{abstract}
Background: Bilimbi is a profusely bearing tree and majority of fruits produced are wasted due to lack of proper preservation methods. Osmo-dehydration studies on quality attributes of bilimbi (Averroha bilimbi) was conducted with the objective to standardize the process variables for osmodehydrated bilimbi and to assess the retention of bioactive compounds.

Mathods: Harvested mature bilimbi fruits of uniform size were washed, surface dried, pricked and blanched in hot water for one minute. Blanched fruits were subjected to osmotic treatment, with sucrose solution of 40,60 and $80^{\circ} \mathrm{B}$ for 60,120 and 180 minutes. The osmodehydrated bilimbi fruits were analyzed for mass transfer, biochemical and sensory qualities. Best treatments were stored for four months in the room temperature.

Result: Mass transfer characters viz., solid gain, water loss, percentage weight reduction, yield and biochemical parameters such as reducing sugar and total sugar increased with increase in osmotic concentration and immersion time whereas free acids, ascorbic acid and antioxidant activity were decreased. The osmotic treatment of $80^{\circ} \mathrm{B}$ for 180 minutes recorded the highest value for solid gain $(5.10 \%)$, water loss $(16.72 \%)$, weight reduction $(22.57 \%)$, ratio of water loss to solid gain $(3.25 \%)$ and yield $(21.13 \%)$ which exhibited superior sensory scores for taste (8.43), flavor (8.27), texture (8.46) and overall acceptability (8.43). The best three treatments selected based on sensory analysis were subjected to storage stability studies under room temperature. Osmodehydrated bilimbi obtained highest sensory score at the end of storage.
\end{abstract}

Key words: Bilimbi, Mass transfer characters, Biochemical parameters, Osmo dehydration, Sensory analysis.

\section{INTRODUCTION}

Averrhoa bilimbi L. commonly known as 'bilimbi' belongs Oxalidaceae family is native to Malaysia and Indonesia. It is an attractive tropical tree commonly known as tree sorrel or cucumber tree. Bilimbi is a profusely bearing tree and majority of production is wasted due to lack of proper preservation methods. Bilimbi fruit has not received much attention as antioxidant sources as compared to other commercial fruits. This might be due to lack of information on nutritional compositions and physical qualities of bilimbi product (Ikram et al. 2009). Bilimbi has been widely used in traditional medicine for cough, cold, itches, boils, rheumatism, syphilis, diabetes, whooping cough (Abas et al., 2006). Mature Averrhoa fruits are acidic, with high fiber content and are high in minerals such as calcium, phosphorous, iron and potassium. These fruits are rich source of vitamin $\mathrm{C}$, antioxidants and are low in fat (Bhaskar and Shantaram, 2013).

Osmo dehydration is considered as an effective method for preservation of fruits and vegetables. According to Sapata et al. (2009) osmotic dehydration (OD) can be named as dewatering and impregnation by immersion in concentrates or by immersion of fruits and vegetable in concentrated solutions or syrups of soluble solids, without phase change. This facilitates processing of fruits and vegetables such as banana, sapota, fig, guava, pineapple, apple mango, grapes, carrots, pumpkins, etc. with retention of initial fruit characteristics like colour, aroma, texture and nutritional composition (Chavan, 2012). This technique can be used
Department of Post Harvest Technology, College of Agriculture, Vellayani, Kerala Agricultural University,Trivandrum-695 522, Kerala, India.

Corresponding Author: G.S. Aparna, Department of Post Harvest Technology, College of Agriculture, Vellayani, Kerala Agricultural University, Trivandrum-695 522, Kerala, India.

Email: aparna.gs3@gmail.com

How to cite this article: Aparna, G.S., Lekshmi, P.R.G., Mini, C. (2022). Effect of Osmo Dehydration on Quality Attributes of Bilimbi (Averroha bilimbi) Fruits. Asian Journal of Dairy and Food Research. DOI: $10.18805 /$ ajdfr.DR-1658.

Submitted: 26-03-2021 Accepted: 25-11-2021 Online: 10-01-2022

for producing high quality products, which provides minimum thermal degradation of nutrients due to low temperature water removal process (Sodhi et al. 2006). In order to reduce acidity of bilimbi fruits, fruits were soaked in sugar solutions of $30,50,65^{\circ} \mathrm{B}$ for 24 hours prior to fermentation (Berkley, 2010). Ruiz-Lopez et al. (2011) conducted a study on carambola fruits and found sucrose as better osmotic agent than fructose and glucose for osmodehydration by favouring greater water loss-to-solute gain ratios at comparable mass transfer rate.

\section{MATERIALS AND METHODS Fruit preparation}

Bilimbi fruits of uniform size, maturity, free from pests, 
diseases and mechanical damages were harvested from the Instructional Farm, Vellayani, Trivandrum, Kerala. Uniform sized bilimbi fruits were pricked and then blanched in hot water for one minute as a pretreatment. Osmotic solutions (sucrose) of three different concentrations viz., 40 , $60,80^{\circ} \mathrm{B}$ were prepared and fruits were immersed in $40^{\circ} \mathrm{B}$ $\left(\mathrm{C}_{2}\right), 60^{\circ} \mathrm{B}\left(\mathrm{C}_{2}\right)$ and $80 \mathrm{p} \mathrm{B}\left(\mathrm{C}_{3}\right)$ osmotic solution (sucrose) for an immersion time of 60 minutes $\left(T_{1}\right) 120$ minutes $\left(T_{2}\right)$ and 180 minutes $\left(T_{3}\right)$. The ratio of fruits to osmotic solution was maintained at 1:2 and the temperature of osmotic solution was maintained at $40^{\circ} \mathrm{C}$. Drained bilimbi fruits were analysed for various mass transfer characters. Osmosed bilimbi fruits were dried in a cabinet tray drier (Gallen Kamp hot box) at a temperature of $50^{\circ} \mathrm{C}$ till the fruits attained a moisture content of $19 \pm 1 \%$. Yield, biochemical parameters and sensory attributes of osmo dehydrated bilimbi were analysed.

\section{Mass transfer characters of osmosed bilimbi}

ass transfer characters viz., solid gain, water loss, percentage weight reduction and ratio of water loss to solid gain (WL/SG) were determined and optimized values were calculated.

\section{Solid gain (\%)}

Solid gain (\%) was determined using the procedure followed by (Kowalski and Mierzwa, 2011).

Where,

$$
S G(\%)=\frac{S_{t}-S_{i}}{m_{i}} \times 100
$$

$S_{t}=$ dry mass at time $t, S_{i}=$ Initial dry mass (of fresh) and $m_{i}=$ initial mass of wet sample.

\section{Water loss (\%)}

Weight of fresh fruit and weight after osmosis was recorded in electronic balance (Cyber Lab-0.01mg to $1000 \mathrm{mg}$ ). Dry mass of fresh fruit and dry mass after osmosis were recorded and water loss in terms of percentage was calculated by the method described by Sridevi and Genitha (2012) using following formula:

$$
W L(\%)=\frac{W_{o}-W_{t}+S_{t}-S_{0}}{W_{0}} \times 100
$$

$W_{0}=$ Initial weight of fruit slices.

$W_{t}=$ Weight of fruit slices after osmotic dehydration.

$\mathrm{S}_{0}=$ Initial dry mass of fruit slices.

$S_{t}=$ Dry mass of fruit slices after osmotic dehydration.

\section{Weight reduction (\%)}

Weight reduction in terms of percentage was calculated using the method described by Jain et al. (2011).

$$
\text { WR }(\%)=\frac{W_{o}-W}{W_{o}} \times 100
$$

Wo $=$ Initial mass of fruit slices prior to osmosis $(\mathrm{g})$. $\mathrm{W}=$ Mass of fruit slices after osmosis $(\mathrm{g})$.

\section{Ratio of water loss to solid gain (WL/SG)}

It is expressed as ratio of calculated value of water loss and solid gain.

$$
\frac{W L}{S G}=\frac{\% \text { water loss }}{\% \text { solid gain }}
$$

Yield (\%)

Weights of osmo dehydrated product obtained from a known quantity of fresh bilimbi fruits were recorded and the yield was calculated using the formula.

$$
\text { Yield }=\frac{\text { Weights of dehydrated fruit }}{\text { Weights of fresh fruit }} \times 100
$$

\section{Biochemical parameters}

Biochemical parameters viz. free acids, total sugar, reducing sugar, vitamin $\mathrm{C}$ and antioxidant activity were analysed. Free acids (\%), reducing sugar (\%), total sugar (\%) and ascorbic acid $(\mathrm{mg} / 100 \mathrm{~g})$ were estimated by the procedures described by Ranganna (1986).

\section{Antioxidant activity (\%)}

Total antioxidant activity of osmo dehydrated bilimbi was determined using 2, 2- diphenyl-1-picrylhydrazyl (DPPH) radical scavenging assay. The scavenging effect on DPPH free radical was measured according to the procedure described by Shen et al. (2010) and was expressed as per cent DPPH as shown in the following equation:

$$
\% \text { inhibition of DPPH }=\frac{\left(A_{0}-A_{1}\right)}{A_{0}} \times 100
$$

Where,

$A_{0}$ - Absorbance of DPPH solution without sample; $A_{1}$ Absorbance of the test sample after $30 \mathrm{~min}$.

\section{Sensory analysis}

Osmo dehydrated bilimbi fruits prepared by different treatments were evaluated for sensory characteristics viz., appearance, colour, flavour, taste, texture and overall acceptability by 30 semi trained members. Each character was given a score from 1 to 9 according to Hedonic rating (Ranganna, 1986). The best three treatments were selected for further storage studies.

\section{Storage studies}

Storage potential of three best osmo dehydrated bilimbi treatments was studied. Osmo dehydrated bilimbi fruits were packed and sealed in polypropylene covers (200 gauge) and were stored at room temperature. The stored products were analyzed for biochemical, sensory and microbial parameters at monthly interval for a period of four months.

\section{Statistical design}

The data generated from experiments were statistically analyzed using completely randomized design (CRD). Sensory parameters were statistically analysed using Kruskall - Wallis Chi-square test. 


\section{RESULTS AND DISCUSSION}

\section{Mass transfer characters}

Mass transfer characters viz., solid gain,weight reduction, water loss and ratio of water loss to solid gain play an important role in the development of osmo-dehydrated products. These were used to indicate the overall exchange of solute and water between bilimbi fruit and osmotic solution. Solid gain of osmosed bilimbi increased with the increase in osmotic concentration and immersion time. Osmo dehydrated bilimbi in $80^{\circ} \mathrm{B}$ for an immersion time of 180 minutes recorded the highest solid gain of 5.10 per cent. These results are in conformation with the findings of Kumar and Devi (2011) for osmodehydration of pineapple. The highest water loss (16.72\%) was observed for osmosed bilimbi in $80^{\circ} \mathrm{B}$ for 180 minutes of immersion time, while lowest water loss $(4.58 \%)$ was in treatment $40^{\circ} \mathrm{B}$ for 60 minutes (Table 1). The results are in line with the findings Rittirut and Siriptana (2007) in osmo dehydrated bilimbi where highest water loss and acid loss was observed for highest concentration $\left(70^{\circ} \mathrm{B}\right)$ and immersion time $(9,000$ $\mathrm{min})$. Osmo-dehydrated bilimbi at $80^{\circ} \mathrm{B}$ for 180 minutes recorded maximum weight reduction of 22.57 per cent followed by osmotic treatment $80^{\circ} \mathrm{B}$ for 120 minutes. Highest water loss with increase in osmotic concentration lead to highest weight reduction of osmo dehydrated product. Ratio of water loss to solid gain (WL/SG)is considered as a good indicator for maximization of water loss and minimisation of solid gain. In the current study, WL/SG recorded a maximum ratio of 3.25 for the treatment $80^{\circ} \mathrm{B}$ for 180 minutes and the lowest ratio (2.17) was observed in $60^{\circ} \mathrm{B}$ for 60 minutes (Table 1). Sharma et al. (2006) reported that during osmodehydration water loss is always favored over solid gain. Osmotic concentration and immersion time significantly influenced yield of dehydrated bilimbi. The highest yield of 21.13 per cent was observed when fruits were immersed in $80^{\circ} \mathrm{B}$ for 180 minutes (Table 1 ). This is in line with the reports of Pedapathi and Tiwari (2014) stated that osmo dehydrated guava in $70^{\circ} \mathrm{B}$ for $24 \mathrm{~h}$ exhibited highest yield of 39.67 per cent.

\section{Biochemical parameters of osmodehydrated bilimbi}

Bilimbi fruit immersed in $80^{\circ} \mathrm{B}$ sucrose solution for 180 minutes recorded the lowest free acid content of 2.31 per cent whereas the highest free acid of 4.16 per cent was shown by the treatment $40^{\circ} \mathrm{B}$ for 60 minutes. Acidity of fruits was decreased with increase in osmotic concentration and immersion time (Fig 1). Rittirut and Siriptatana, (2009) also reported that during osmodehydration of bilimbi fruits acid loss increased with increase in syrup concentration. Reduction in acidity can be attributed to the leaching of acid from fruits to the osmotic solution through a semi permeable membrane (Sagar and Kumar, 2009a). Ascorbic acid content of osmo dehydrated bilimbi decreased with increase in concentration and immersion time. The highest percent of ascorbic acid $(34.26 \mathrm{mg} / 100 \mathrm{~g})$ was noticed in treatment $40^{\circ} \mathrm{B}$ for 60 minutes and the lowest ascorbic acid $(21.66 \mathrm{mg} / 100$ g) was for bilimbi osmosed in $80^{\circ} \mathrm{B}$ for 180 minutes (Table
2). Ascorbic acid losses during osmotic dehydration might be attributed to the leaching of the vitamin from the product to the osmotic solution during the osmotic process (Nadia et al. 2013). Bilimbi osmo-dehydrated in $80^{\circ} \mathrm{B}$ for 180 minute recorded highest total sugar (18.53\%) and reducing sugar $(8.24 \%)$ (Table 2). Sagar and Kumar, (2009b) reported that osmotic drying substantially increased sugar content and reduced acidity without changing colour, texture and original flavour of mango fruit slices.

\section{Sensory analysis}

Osmotic concentration and immersion time significantly influenced the sensory quality viz., taste, colour, flavour, texture and overall acceptability. It was observed that $80^{\circ} \mathrm{B}$ with 180 minutes immersion time recorded highest mean score for taste (8.43), flavour (8.27), texture (8.47) and overall acceptability (8.43). Fruits immersed in $60^{\circ} \mathrm{B}$ for 180 minutes obtained the highest (8.23) sensory score for colour

Table 1: Effect of osmodehydration on mass transfer characters of bilimbi.

\begin{tabular}{|c|c|c|c|c|}
\hline \multirow{2}{*}{$\begin{array}{l}\text { Osmotic } \\
\text { concentrations }\end{array}$} & \multicolumn{3}{|c|}{ Immersion time (minutes) } & \multirow[b]{2}{*}{$\begin{array}{c}\text { Mean } \\
\text { (C) }\end{array}$} \\
\hline & $\begin{array}{c}T_{1} \\
(60)\end{array}$ & $\begin{array}{c}\mathrm{T}_{2} \\
(120)\end{array}$ & $\begin{array}{c}T_{3} \\
(180)\end{array}$ & \\
\hline & \multicolumn{3}{|c|}{ Solid gain (SG) (\%) } & \\
\hline $\mathrm{C}_{1}\left(40^{\circ} \mathrm{B}\right)$ & 2.03 & 2.37 & 2.63 & 2.34 \\
\hline $\mathrm{C}_{2}\left(60^{\circ} \mathrm{B}\right)$ & 3.33 & 3.83 & 4.33 & 3.83 \\
\hline $\mathrm{C}_{3}\left(80^{\circ} \mathrm{B}\right)$ & 4.30 & 4.67 & 5.10 & 4.69 \\
\hline Mean $(T)$ & 3.22 & 3.62 & 4.02 & \\
\hline \multirow[t]{2}{*}{ CD (0.05) } & \multicolumn{3}{|c|}{ C/T-0.0-.085 CxT-0.143 } & \\
\hline & \multicolumn{3}{|c|}{ Water loss (\%) } & \\
\hline $\mathrm{C}_{1}\left(40^{\circ} \mathrm{B}\right)$ & 4.58 & 5.60 & 7.16 & 5.78 \\
\hline $\mathrm{C}_{2}\left(60^{\circ} \mathrm{B}\right)$ & 7.25 & 9.26 & 10.45 & 8.98 \\
\hline $\mathrm{C}_{3}\left(80^{\circ} \mathrm{B}\right)$ & 9.81 & 14.04 & 16.72 & 13.52 \\
\hline Mean $(T)$ & 7.21 & 9.63 & 11.44 & \\
\hline \multirow[t]{2}{*}{ CD (0.05) } & \multicolumn{2}{|c|}{$\mathrm{C} / \mathrm{T}-0.257$} & $\mathrm{~T}-0.445$ & \\
\hline & \multicolumn{3}{|c|}{ WL/SG } & \\
\hline $\mathrm{C}_{1}\left(40^{\circ} \mathrm{B}\right)$ & 2.26 & 2.44 & 2.72 & 2.47 \\
\hline $\mathrm{C}_{2}\left(60^{\circ} \mathrm{B}\right)$ & 2.17 & 2.41 & 2.27 & 2.29 \\
\hline $\mathrm{C}_{3}\left(80^{\circ} \mathrm{B}\right)$ & 2.43 & 3.01 & 3.25 & 2.90 \\
\hline Mean $(\mathrm{T})$ & 2.29 & 2.62 & 2.75 & \\
\hline \multirow[t]{2}{*}{ CD (0.05) } & \multicolumn{3}{|c|}{ C/T-0.114 CxT-0.198 } & \\
\hline & \multicolumn{3}{|c|}{ Weight reduction (\%) } & \\
\hline $\mathrm{C}_{1}\left(40^{\circ} \mathrm{B}\right)$ & 6.73 & 8.30 & 10.02 & 8.35 \\
\hline $\mathrm{C}_{2}\left(60^{\circ} \mathrm{B}\right)$ & 10.91 & 13.23 & 15.17 & 13.10 \\
\hline $\mathrm{C}_{3}\left(80^{\circ} \mathrm{B}\right)$ & 14.70 & 19.39 & 22.57 & 18.88 \\
\hline Mean $(T)$ & 10.79 & 13.64 & 15.76 & \\
\hline \multirow[t]{2}{*}{ CD (0.05) } & \multicolumn{2}{|c|}{$\mathrm{C} / \mathrm{T}-0.267$} & .463 & \\
\hline & \multicolumn{3}{|c|}{ Yield (\%) } & \\
\hline $\mathrm{C}_{1}\left(40^{\circ} \mathrm{B}\right)$ & 18.03 & 18.3 & 18.63 & 18.32 \\
\hline $\mathrm{C}_{2}\left(60^{\circ} \mathrm{B}\right)$ & 19.33 & 19.83 & 20.27 & 19.81 \\
\hline $\mathrm{C}_{3}\left(80^{\circ} \mathrm{B}\right)$ & 20.00 & 20.67 & 21.13 & 20.60 \\
\hline Mean $(T)$ & 19.12 & 19.60 & 20.01 & \\
\hline CD (0.05) & \multicolumn{2}{|c|}{$\mathrm{C} / \mathrm{T}-0.134$} & 233 & \\
\hline
\end{tabular}


Effect of Osmo Dehydration on Quality Attributes of Bilimbi (Averroha bilimbi) Fruits

followed by the treatment $80^{\circ} \mathrm{B}$ for $180 \mathrm{~min}$ (8.17) (Table 3). Studies conducted by Prasannath and Mahendran (2009) in osmo-dehydrated jackfruit and Nadia et al. (2013) in pear revealed the positive effect of osmotic dehydration on sensory qualities.

\section{Storage studies}

The best three treatments viz., A1 (fruit osmosed in $60^{\circ}$ Brix for 180 minutes), A2( fruit osmosed in $80^{\circ}$ Brix for 120 minutes) and $\mathrm{A} 3$ (fruit osmosed in $80^{\circ} \mathrm{Brix}$ for 180 minutes) kept under room temperature were analyzed for biochemical quality at monthly intervals (Table 4). Free acid content of osmo-dehydrated bilimbi fruits were reduced during storage. Osmo-dehydrated bilimbi treated after immersion in $60^{\circ} \mathrm{B}$ for 180 minutes recorded decrease in free acid content from 2.74 per cent to $2.54 \%$ and 2.32 per cent to 2.06 per cent for $80^{\circ} \mathrm{B}$ in 180 minutes after storage. The decrease in acidity during storage might be due to bio-conversion of acids into sugars (Lal et al., 2015). Reducing sugar and total sugar content of osmo-dehydrated bilimbi increased slightly during storage but there was no significant difference among the osmotic treatment. Similar results were reported by Sagar and Kumar (2009b) in mango. Total sugar of treatment increased from $18.56 \%$ to $19.55 \%$ after a period of 4 months. The increase in total sugar content during storage is in consonance with Prasannath and Mahendran (2009). This could be explained by the fact that the polysaccharides might have converted into monosaccharide (Lal et al., 2015). Ascorbic acid showed a decreasing trend in all the treatments over a storage period of four months at ambient conditions. During storage, ascorbic acid of osmo dehydrated bilimbi in $60^{\circ} \mathrm{B}$ for 180 minutes immersion time was decreased from 24.65 to $23.00 \mathrm{mg} / 100 \mathrm{~g}$ and treatment with $80^{\circ} \mathrm{B}$ for 120 minutes recorded reduction in ascorbic acid from 22.49 to $20.97 \mathrm{mg} / 100 \mathrm{~g}$. A similar trend in reduction of ascorbic acid was also observed Lal et al. (2015). Osmo dehydrated bilimbi in $60^{\circ} \mathrm{B}$ for 180 minutes of immersion recorded highest antioxidant activity of 49.58 per cent at the time of storage and which reduced to 46.79 per cent after fourth month of storage (Fig 2). Osmotic treatment at $80^{\circ} \mathrm{B}$ for 180 minutes was found as the best treatment for
Table 2: Effect of osmodehydration on biochemical parameters of osmodehydrated bilimbi.

\begin{tabular}{|c|c|c|c|c|}
\hline \multirow{4}{*}{$\begin{array}{l}\text { Osmotic } \\
\text { concentrations }\end{array}$} & \multicolumn{3}{|c|}{ Biochemical parameter } & \multirow[b]{4}{*}{ Mean $(\mathrm{C})$} \\
\hline & \multicolumn{3}{|c|}{ Ascorbic acid $(\mathrm{mg} / 100 \mathrm{~g})$} & \\
\hline & \multicolumn{3}{|c|}{ Immersion time (minutes) } & \\
\hline & $\mathrm{T}_{1}(60)$ & $\mathrm{T}_{2}(120)$ & $\mathrm{T}_{3}(180)$ & \\
\hline $\mathrm{C}_{1}\left(40^{\circ} \mathrm{B}\right)$ & 34.26 & 33.07 & 30.05 & 32.46 \\
\hline $\mathrm{C}_{2}\left(60^{\circ} \mathrm{B}\right)$ & 33.15 & 28.98 & 25.14 & 29.08 \\
\hline $\mathrm{C}_{3}\left(80^{\circ} \mathrm{B}\right)$ & 25.29 & 23.05 & 21.66 & 23.34 \\
\hline Mean $(T)$ & 30.90 & 28.37 & 25.62 & \\
\hline \multirow[t]{2}{*}{ CD (0.05) } & \multicolumn{3}{|c|}{ C/T-0.381 CXT-0.66 } & \\
\hline & \multicolumn{3}{|c|}{ Reducing sugar (\%) } & \\
\hline $\mathrm{C}_{1}\left(40^{\circ} \mathrm{B}\right)$ & 3.72 & 4.21 & 4.98 & 4.30 \\
\hline $\mathrm{C}_{2}\left(60^{\circ} \mathrm{B}\right)$ & 4.36 & 5.15 & 6.24 & 5.25 \\
\hline $\mathrm{C}_{3}\left(80^{\circ} \mathrm{B}\right)$ & 6.19 & 7.06 & 8.24 & 7.17 \\
\hline Mean $(T)$ & 4.76 & 5.65 & 6.49 & \\
\hline \multirow[t]{2}{*}{$C D(0.05)$} & \multicolumn{3}{|c|}{ C/T-0.175 CXT-0.303 } & \\
\hline & \multicolumn{3}{|c|}{ Total sugar (\%) } & \\
\hline $\mathrm{C}_{1}\left(40^{\circ} \mathrm{B}\right)$ & 11.44 & 12.06 & 12.82 & 12.12 \\
\hline $\mathrm{C}_{2}\left(60^{\circ} \mathrm{B}\right)$ & 12.58 & 14.86 & 16.59 & 14.68 \\
\hline $\mathrm{C}_{3}\left(80^{\circ} \mathrm{B}\right)$ & 16.17 & 17.61 & 18.53 & 17.43 \\
\hline Mean $(T)$ & 13.40 & 14.84 & 15.98 & \\
\hline $\mathrm{CD}(0.05)$ & \multicolumn{2}{|c|}{$\mathrm{C} / \mathrm{T}-0.268$} & -0.219 & \\
\hline
\end{tabular}

Table 3: Sensory analysis of osmodehydrated bilimbi.

\begin{tabular}{lccccc}
\hline Treatments & Taste & Colour & Flavour & Texture & $\begin{array}{c}\text { Overall } \\
\text { Acceptabiliy }\end{array}$ \\
\hline $\mathrm{C}_{1} \mathrm{~T}_{1}$ & 6.87 & 6.57 & 6.90 & 6.73 & 6.77 \\
$\mathrm{C}_{1} \mathrm{~T}_{2}$ & 7.17 & 6.63 & 6.93 & 6.93 & 6.97 \\
$\mathrm{C}_{1} \mathrm{~T}_{3}$ & 7.40 & 6.70 & 7.30 & 7.17 & 7.20 \\
$\mathrm{C}_{1} \mathrm{~T}_{1}$ & 7.53 & 7.17 & 7.57 & 7.07 & 7.13 \\
$\mathrm{C}_{2} \mathrm{~T}_{2}$ & 7.83 & 7.30 & 7.70 & 8.00 & 7.97 \\
$\mathrm{C}_{2} \mathrm{~T}_{3}$ & 8.30 & 8.23 & 7.97 & 8.40 & 8.33 \\
$\mathrm{C}_{3} \mathrm{~T}_{1}$ & 8.17 & 8.13 & 7.90 & 8.10 & 8.10 \\
$\mathrm{C}_{3} \mathrm{~T}_{2}$ & 8.33 & 8.17 & 8.00 & 8.40 & 8.40 \\
$\mathrm{C}_{3} \mathrm{~T}_{3}$ & 8.43 & 8.13 & 8.27 & 8.47 & 8.43 \\
$\mathrm{KW}$ value & 99.84 & 150.64 & 155.57 & 200.93 & 184.54 \\
$\chi^{2}(0.05)$ & \multicolumn{5}{c}{15.50} \\
\hline
\end{tabular}

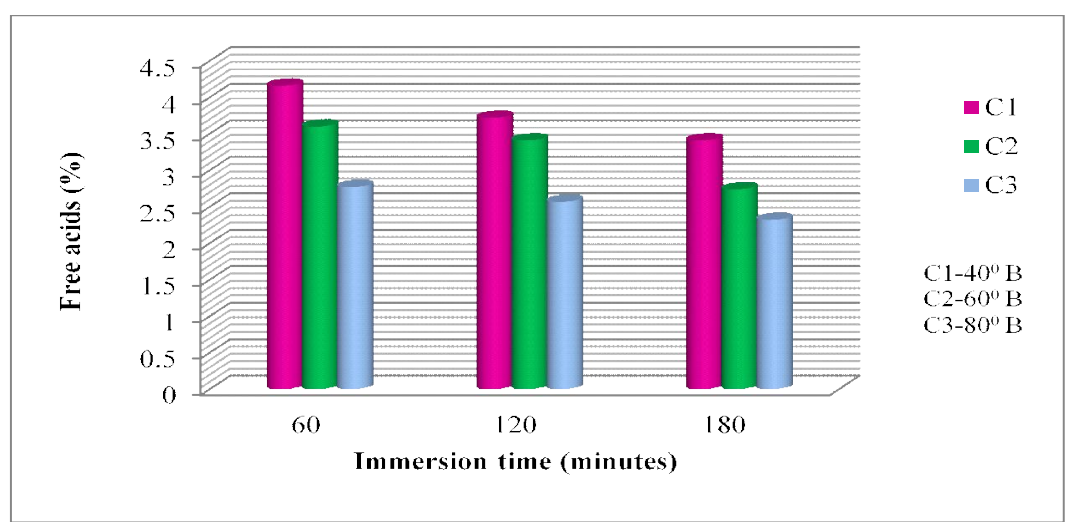

Fig 1: Effect of osmotic concentration and immersion time on free acids (\%) of osmo dehydrated bilimbi. 
Effect of Osmo Dehydration on Quality Attributes of Bilimbi (Averroha bilimbi) Fruits

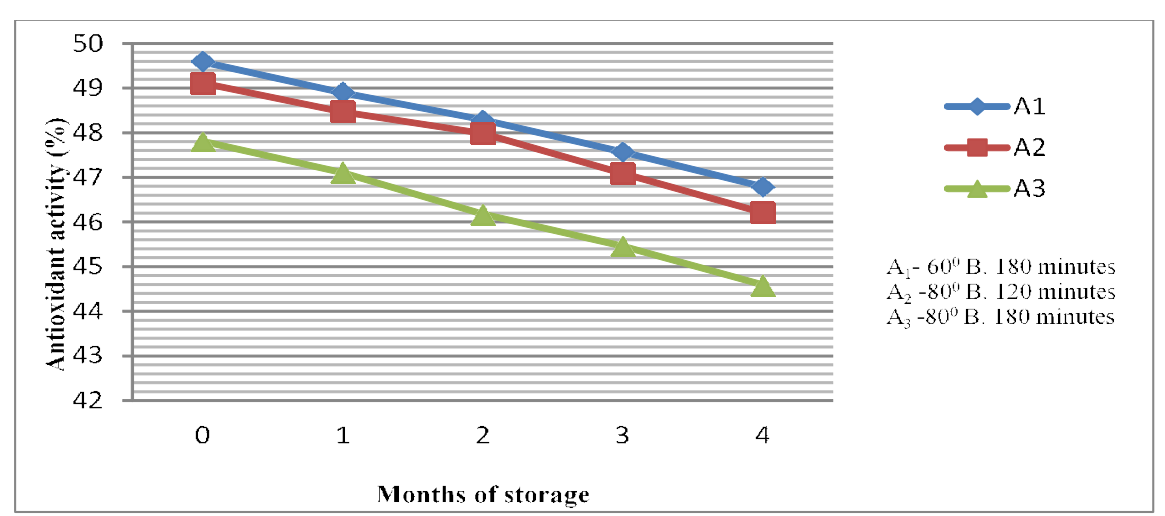

Fig 2: Effect of storage on antioxidant activity (\%) of osmo dehydration.

Table 4: Effect of storage on biochemical parameters of osmo dehydrated bilimbi.

\begin{tabular}{|c|c|c|c|c|c|c|}
\hline \multirow{2}{*}{$\begin{array}{l}\text { Osmodehydrated } \\
\text { bilimbi }\end{array}$} & \multicolumn{5}{|c|}{ Months after storage (M) } & \multirow{2}{*}{ Mean $(A)$} \\
\hline & 0 & 1 & 2 & 3 & 4 & \\
\hline \multicolumn{7}{|c|}{ Free acids (\%) } \\
\hline A & 2.74 & 2.67 & 2.63 & 2.59 & 2.54 & 2.63 \\
\hline$A^{1}$ & 2.60 & 2.53 & 2.45 & 2.40 & 2.37 & 2.47 \\
\hline$A^{2}$ & 2.32 & 2.26 & 2.22 & 2.16 & 2.06 & 2.20 \\
\hline Mean (M) & 2.55 & 2.48 & 2.43 & 2.38 & 2.32 & \\
\hline \multirow[t]{3}{*}{ CD A-0.009 } & \multicolumn{5}{|c|}{$M-0.011 \mathrm{~A} \times \mathrm{M}-0.019$} & \\
\hline & \multicolumn{5}{|c|}{ Reducing sugar (\%) } & \\
\hline & 0 & 1 & 2 & 3 & 4 & Mean $(A)$ \\
\hline A & 6.24 & 6.35 & 6.43 & 6.51 & 6.61 & 6.43 \\
\hline$A^{1}$ & 7.62 & 7.73 & 7.89 & 8.09 & 8.18 & 7.9 \\
\hline$A^{2}$ & 8.25 & 8.36 & 8.48 & 8.55 & 8.75 & 8.48 \\
\hline Mean (M) & 7.37 & 7.48 & 7.60 & 7.72 & 7.85 & \\
\hline \multirow[t]{3}{*}{ CD A-0.068 } & \multicolumn{5}{|c|}{$\mathrm{M}-0.087 \mathrm{~A} \times \mathrm{M}-\mathrm{NS}$} & \\
\hline & \multicolumn{5}{|c|}{ Total sugar (\%) } & \\
\hline & 0 & 1 & 2 & 3 & 4 & Mean(A \\
\hline A & 16.58 & 16.74 & 16.95 & 17.32 & 17.56 & 17.03 \\
\hline$A^{1}$ & 17.54 & 17.76 & 17.92 & 18.40 & 18.82 & 18.09 \\
\hline$A^{2}$ & 18.56 & 18.68 & 18.95 & 19.26 & 19.55 & 19 \\
\hline Mean (M) & 17.56 & 17.73 & 17.94 & 18.33 & 18.64 & \\
\hline \multirow[t]{3}{*}{ CD A-0.107 } & & & A & & & \\
\hline & \multicolumn{5}{|c|}{ Ascorbic acid $(\mathrm{mg} / 100 \mathrm{~g})$} & \\
\hline & 0 & 1 & 2 & 3 & 4 & Mean $(A)$ \\
\hline A & 25.30 & 24.65 & 24.05 & 23.57 & 23 & 24.12 \\
\hline$A^{1}$ & 23.02 & 22.49 & 22.09 & 21.45 & 20.97 & 22.00 \\
\hline$A^{2}$ & 21.95 & 21.15 & 20.6 & 19.93 & 19.29 & 20.58 \\
\hline Mean (M) & 23.42 & 22.77 & 22.25 & 21.65 & 21.09 & \\
\hline CD (0.05) & & & $-0.131 \mathrm{~A}$ & & & \\
\hline
\end{tabular}

$\mathrm{A}_{1}\left(60^{\circ} \mathrm{B}, 180\right.$ minutes, $\mathrm{A}_{2}\left(80^{\circ} \mathrm{B}, 120\right.$ minutes $) \mathrm{A}_{3}\left(80^{\circ} \mathrm{B}, 180\right.$ minutes $)$.

development of osmo-dehydrated bilimbi as it retained the stability and biochemical quality during storage. According to Aparna et al. (2018) osmodehydrated bilimbi fruits were found to be microbiologically stable for a period of for months.

\section{CONCLUSION}

The study was conducted with the objective to standardize the process variables for osmo dehydrated bilimbi. Blanched fruits were subjected to osmotic treatment with sucrose solution of 40,60 and $80^{\circ} \mathrm{B}$ for 60,120 and 180 minutes. Mass transfer characters viz., solid gain, water loss, percentage weight reduction, yield and biochemical parameters such as reducing sugar and total sugar increased with increase in osmotic concentration and immersion time whereas free acids, ascorbic acid and antioxidant activity decreased. The stored osmo dehydrated 
bilimbi fruits were analyzed for biochemical quality at monthly intervals. During storage, reducing and total sugars increased while ascorbic acid, antioxidant activity and free acids decreased. Osmodehydrated bilimbi in $80^{\circ} \mathrm{B}$ for an immersion time of 180 minutes recorded $2.06 \%$ free acid content, $19.55 \%$ total sugar, $8.75 \%$ reducing sugar, $19.29 \%$ vitamin $\mathrm{C}$ and $44.59 \%$ antioxidant activity at the end of four months of storage.

\section{ACKNOWLEDGEMENT}

The authors acknowledge the Kerala Agricultural University, kerala, India for the facilities granted.

\section{REFERENCES}

Abas, F., Lajis, N.H., Israf, D.A., Khozirah, S. and Kalsom, Y.U. (2006). Antioxidant and nitric oxide inhibition activities of selected Malay traditional vegetables. Food Chemistry. 95: 566-573.

Aparna, G.S. Lekshmi, G.P.R. Mini, C. and Chandran,T.T. (2018). Studies on sensory attributes and microbial analysis of stored osmo dehydrated bilimbi (Averroha bilimbi) Asian Journal of Dairy and Food Research. 37(2): 154-157.

Berkley, F.O. (2010). Fermentation of Bilimbi (Averrhoa bilimbi L.) Wines: Physicochemical and Sensory characteristics. MSc (Food and agri.). University of West Indies. 51p.

Bhaskar, B. and Shantaram, M. (2013). Morphological and biochemical characteristics of Averrhoa fruits. International Journal of Pharmaceutical, Chemical and Biological Sciences. 3(3): 924-928.

Chavan, U.D. (2012). Osmotic dehydration process for preservation of fruits and vegetables. Journal of Food Research. 1(2): 202-209.

Ikram, E.H.K., Khoo, H.E., Jalil, A.M.M., Ismail, A., Idris, S., Azlan, A., Nazri, H.S.M., Dito, N.A.M. and Mokhtar, R.A.M. (2009). Antioxidant activity and total phenolic content of Malaysian underutilized fruits. Journal of Food Composition and Analysis. 22: 388-393.

Jain, S.K., Verma, R.J.C., Murdia, L.K., Jain, H.K., Sharma, G.P. (2011). Optimization of process parameters for osmotic dehydration of papaya cubes. Food Science and Technology. 48(2): 211-217.

Kowalski, S.J. and Mierzwa, D. (2011). Influence of preliminary osmotic dehydration on drying kinetics and final quality of carrot (Daucus carota L). Chemical Engineering and Processing. 32(3): 185-194.

Kumar, S.P. and Devi, P. (2011). Optimization of some process variable in mass transfer kinetics of osmotic dehydration of pineapple slices. International Food Research Journal. 18: 221-238.

Lal, U., Sood, M. and Kaul, R. (2015). Effect of different treatments on quality and sensory attributes of osmo-dehydrated wild apricot. Indian Journal of Horticulture. 72(3): 392-396.

Nadia, D.M.B.M.N., Nabil, K., Courtois, F. and Bonazzi, C. (2013). Effect of osmo-dehydration conditions on the quality attributes of pears. Journal of Food Processing and Technology. 4: 8-9.
Pedapati, A. and Tiwari, R.B. (2014). Effect of different osmotic pretreatments on weight loss, yield and moisture loss in osmotically dehydrated guava. Journal of Agri Search. 1(1): 49-54.

Prasannath, K. and Mahendran, T. (2009). Physico-chemical and sensory attributes of osmotically dehydrated Jackfruit (Artocarpus heterophyllus Lam.). Journal of Food and Agriculture. 2(1): 8-14.

Ranganna, S. (1986). Handbook of Analysis and Quality Control for Fruit and Vegetable Products. Tata McGraw-Hill Publishing Company Limited, New Delhi. 182p.

Rittirut, W. and Siripatana, C. (2007). Osmotic Dehydration of Bilimbi Fruit (Averrhoa bilimbi). In: Proceedings of the International Conference on Agricultural, Food and Biological Engineering and Post Harvest/Production Technology TSAE and ASABE, Khon Kaen, Thailand., pp. 1-31.

Rittirut, W. and Siripatana, C. (2009). The influence of operating temperature on mass transfer characteristics during a diffusion process in bilimbi fruit. Walilak Journal of Science and Technology. 6(1): 59-78.

Ruiz-Lopez, I., Ruiz-Espinosa, H., Herman-Lara, E. and ZarateCastillo, G. (2011). Modeling of kinetics, equilibrium and distribution data of osmotically dehydrated carambola (Averrhoa carambola L.) in sugar solutions. Journal of Food Engineering. 104: 218-226.

Sagar, V.R. and Kumar, S.P. (2009a). Effect of osmosis on chemical parameters and sensory attributes of mango, guava slices and aonla segments. Indian Journal of Horticulture. 66(1): 53-57.

Sagar, V.R. and Kumar, S.P. (2009b). Involvement of some process variables in process transfer kinetics of osmotic dehydration of mango slices and storage stability. Journal of Scientific and Industrial Research. 68: 1043-1048.

Sapata, M.L., Ferreira, A. andrada, L., Leitão, A. E. and Candeias, M. (2009). Osmoticdehydration of mandarins: influence of reutilized osmotic agent on behaviour and product quality. Acta Scientiarum Polonorum Technologia Alimentaria. 8: 23-35.

Sharma, H.R., Handa, P. and Verma, R. (2006).Organoleptic and chemical evaluation of osmotically processed apricot wholes and halves. Natural Product Radiance. 5: 350-56.

Shen ,Q., Zhang, B., Xu, R., Wang, Y., Ding.X. and Li, P. (2010). Antioxidant activity in vitro of the Selenium-contained protien from the Se-enriched Bifidobacterium animalis 01. Anaerobe. 16(4): 380-386.

Sodhi, N.S., Singh, N. and Komal. (2006). Osmotic dehydration kinetics of carrots. Journal of Food Science and Technology. 43: 374-376.

Sridevi, M. and Genitha, T.R. (2012). Optimization of osmotic dehydration process of pineapple by response surface methodology. Journal of Food Processing Technology. 3: 173. 